\title{
Analysis of Anti-Allergic Activities by Chaff Vinegar Liquor
}

\section{Sang-Han Lee*}

Food E Bio-Industry Research Institute, and Department of Food Science E Biotechnology, Kyungpook National University, Daegu 702-701, Korea

Received February 4, 2010 /Accepted May 17, 2010

\begin{abstract}
To evaluate whether chaff vinegar liquor (CVL) has potential in ameliorating allergic symptoms in mice, we tested the anti-allergic activities with a DNFB (dinitrofluorobenzene)-induced allergic mouse model. The DNFB-induced allergic symptoms were reduced by $20 \%$ compared to the control by chaff vinegar liquor supplemented with Perilla frutescens var. acuta. Allergic symptoms were examined by measuring the width of epidermis swelling. The hematoxyline \& eosin (H\&E) staining also revealed that the chaff vinegar liquor dramatically decreased the allergic symptoms in the epidermis of the ear. These results collectively suggest that the chaff vinegar liquor supplemented with $P$. frutescens var. acuta has potential in ameliorating allergic symptoms, showing that the liquor could be a useful biomaterial(s) for the nutraceutical or cosmetic industries.
\end{abstract}

Key words : Allergy, chaff, liquor, Perilla frutescens var. acuta, extraction

\section{서 론}

Allergy란 선천적 또는 후천적으로 면역기능의 현상으로 서, allergen이라 불리는 외부 물질과의 접촉에 의하여 발생하 는 과민한 반응을 나타내는 것으로, 이에 대한 질환으로는 anaphylaxis, allergic rhinitis, asthma, atopic dermatitis, 곤충 allergy, 식품 allergy, 약품 allergy 및 두드러기(urticaria) 등이 있다 $[9,13]$. Dinitrofluorobenzene (DNFB)는 지연형 접촉성 피 부염을 일으키는 대표적인 물질로 $\mathrm{DNFB}$ 의 반복 노출 시 $\mathrm{CD}^{+}$및 $\mathrm{CD} 8^{+} \mathrm{T}$ 세포 매개성 염증세포의 침윤(infiltration)에 의한 피부 부종과 피부 조직의 비후가 초래되는 것으로 알려 져 있으며, DNFB 유발 접촉성 피부염 동물모델은 현재 가장 널리 이용되고 있는 allergy 동물 모델 중 하나이다[1,7]. Allergen이 $\mathrm{IgE}$ 에 의해 인식되면 Langerhans cell 표면 $\operatorname{IgE}$ 부 착 $\mathrm{Fc}$ 수용체에 부착되어 $\mathrm{T}$ 림프구에 항원을 전달함으로써 $\mathrm{T}$ 림 프구가 활성화되게 된다. 다른 피부질환과 달리 아토피 피부 염의 피부병변에 침윤되는 염증세포는 주로 $\mathrm{Th} 2$ 세포로서 IL-4, IL-5, IL-13 등의 사이토카인을 과다하게 생성하여 혈중 $\mathrm{IgE}$ 의 상승을 촉진하고 eosinophil의 증가를 유도하며, cAMP phosphodiesterase가 상승되어 있는 아토피 피부염의 비정상 적인 monocyte에 의해 prostaglandin $\mathrm{E}$ 의 생성이 증가하게 되고, 이로 인해 Th1 림프구의 침윤이 억제된다. 또한 Th1 림 프구는 아토피 피부염에서 쉽게 활성화되는 spleen cell로부터 유리된 TNF (tumor necrosis factor)에 의해서도 억제된다. 결 국 아토피 피부염에서 Th1 증식을 억제하고, 세포매개성 면역

\footnotetext{
*Corresponding author

Tel : +82-53-950-7754, Fax : +82-53-950-6772

E-mail : sang@knu.ac.kr
}

의 저하를 초래한다. 각종 사이토카인(cytokines)은 혈관 내피 세포를 활성화하여 여러 세포유착분자의 발현을 유도하거나 증가시켜 기억 $\mathrm{T}$ 림프구의 복귀를 촉진시킴으로서 습진성 병 변을 유발한다[3].

왕겨는 벼의 껍질로, 쌀 가공과정에서 생겨나는 가장 많은 양의 부산물로서 벼 중량의 $20 \%$ 를 차지한다. 국내 왕겨 생산 량은 2007년 기준으로 보면, 연간 약 120 만톤의 왕겨가 생산이 되고 있으며, 주로 에너지원으로서 적당한 특성을 가지고 있 지만, 폐기물로 분류되어 있는 실정이다. 왕겨의 내피나 외피 는 규소로 치밀하게 피복되어 있어서 부식이나 소화 효율이 낮기 때문에 퇴비나 가축의 사료로는 부적합한 것으로 알려져 있다. 이러한 왕겨의 주요 구성성분은 탄수화물이 $27 \sim 30 \%$, 조 섬유질 35 46\%, 조회분 13 21\%, 조단백 2 3\% 그리고 조지방 $0.3 \sim 0.8 \%$ 정도로 들어 있으며, 조회분의 주성분은 규소로 알려 져 있다 [8]. 이와 같은 특성을 지닌 왕겨는 다른 용도도 없고 마땅한 처리방법도 없어서 왕겨의 합리적인 이용 및 폐기물을 이용하여 고부가가치화는 농가의 소득증진에도 매우 의미가 있다.

이에 본 연구는 이 왕겨를 재료로 하여 제조된 왕겨 증류액 이 $\mathrm{DNCB}$ 에 의해 유발되는 접촉성 피부염 allergy 질환 동물 모델에 적용하였을 때, 환부조직에서 allergy 반응의 주된 항 체인 $\mathrm{IgE}$ 의 생성을 억제하고, 진피, 상피 및 피부의 전체 두께 를 감소시킴을 확인함으로써, anti-allergy 효과를 확인하였으 므로 이에 보고하는 바이다.

\section{재료 및 방법}

왕겨초 증류액(CVL) 제조

본 실험에 사용한 왕겨초 증류액(chaff vinegar liquor; 
$\mathrm{CVL})$ 은 다음과 같이 제조하였다. 먼저, 선산 미곡종합처리장 으로부터 제공받은 왕겨 $400 \mathrm{~kg}$ 을 탄화기(DCH-600, 대원GSI) 를 사용하여 직화식 탄화법에 의하여 왕겨초 증류액을 포집하 고, 왕겨를 $500^{\circ} \mathrm{C}$ 에서, 60 분 동안 탄화 처리한 뒤, 상기 탄화 처리 중에 배출되는 연기를 응축시켜 조왕겨초 증류액 $(80 \mathrm{~kg}$, $20 \%$ )을 얻었으며, 이 조왕겨초 증류액을 감압하여 $50^{\circ} \mathrm{C}$ 의 온 도에서 왕겨초 증류액(CVL) $50 \mathrm{~kg}$ 을 수득하였다. 왕겨초 증류 액 $(\mathrm{CVL})$ 은 식염수를 사용하여 $1 / 10$ 농도로 희석하여 사용하 였으며[12], 산쑥과 자소엽은 $2 \%$ 농도로 첨가하였는데 이는 왕겨초액 특유의 이취를 제거할 목적으로 첨가하였다. 대조군 은 식염수를 사용하였다.

\section{실험동물 준비 및 관리}

6주령 된 C57B/L 마우스를 샘타코(주)에서 공급받아 마우 스용 케이지 $(220 \times 200 \times 145 \mathrm{~mm})$ 에 넣어 약 1 주간 순화과정을 거친 후 사용하였다. 동물실험실의 환경은 온도 $22^{\circ} \mathrm{C}\left(2^{\circ} \mathrm{C}\right.$ 오 차), 상대습도 $55 \%$ ( $5 \%$ 오차), 환기횟수 12 회/시간, 조명주기 12시간, 조도 $200 \mathrm{lux}$ 로 조절되었다. 실험동물용 pellet형 고형 사료인 Purina Rat Chow를 Nestle Purina PetCare Korea Ltd. (Seoul, Korea)로부터 공급받아 급여하였으며, 음수는 멸균정 제수를 자유롭게 섭취하도록 하였다[5].

\section{접촉성 피부염(아토피) 실험}

Allergy 반응 억제효과를 측정하기 위해서, 다음과 같은 실 험동물의 care하에서 수행하였다[11]. 사육한 마우스는 제모 제를 충분히 사용하여 등 부위를 넓게 제모하고 24 시간 후 올리브 오일과 아세톤을 $3: 1$ 로 배합한 용액에 $0.5 \%$ 의 농도로 조제한 DNFB $100 \mathrm{ul}$ 를 취하여 처음 3일은 sensitization을 위 하여 매일 동일한 시간에 도포하여 피부염을 유발하였다. 이 후 $\mathrm{DNFB}$ 는 $0.2 \%$ 로 농도를 조정하여 $100 \mathrm{ul}$ 씩 취하여, 왕겨초 증류액 $(\mathrm{CVL})$ 혹은 식염수(대조군)와 동시에 2주 동안 격일로 동일한 시간에 도포하였다. 2주 후, 실험 24시간 전부터 절식 시키고 가벼운 에테르 마취상태에서 복개 후 심장에서 혈액을 채취하고, 간과 피부조직을 적출하여 중량을 측정한 후 냉동 보관하였다. 귀의 피부조직은 절개하여 포르말린에 고정시키 고 $\mathrm{H} \& \mathrm{E}$ 염색을 수행하였다[4].

\section{통계학적 분석}

실험결과에 대하여 one-way analysis of variance, ANOVA 를 실시하여 유의차가 $5 \%$ 미만 $(\mathrm{p}<0.05)$ 일 때 통계적 유의성이 있는 것으로 판정하였다[2].

\section{결과 및 고찰}

본 실험에 사용된 재료는 왕겨를 직화식 탄화에 의하여 왕 겨초 증류액을 얻었으며, 이를 사용하여 다음과 같은 동물실
험을 통하여 접촉성 피부염 활성을 예비검증하였다. 본 실험 에 사용한 동물은 외부의 allergen으로서 $\mathrm{DNFB}$ 를 처리한 마 우스로서 피부조직에서 조직병리학적 염색과 피부 중 가장 민감한 귀의 표피의 부종(swelling)의 감소를 측정하는 것으로 접촉성 피부염 효과를 확인하였다.

$\mathrm{DNFB}$ 는 지연형 접촉성 피부염을 일으키는 전형적인 물질 로 $\mathrm{DNFB}$ 의 반복 노출 시, $\mathrm{CD}^{+}$및 $\mathrm{CD}^{+} \mathrm{T}$ 세포 매개성 염증세 포의 침윤(infiltration)에 의한 피부 부종과 피부 조직의 비후 가 초래되는 것으로 알려져 있으며, DNFB 유발 접촉성 피부 염 동물모델은 현재 가장 널리 이용되고 있는 실험동물 모델 중 하나이다[1,7]. 조직학적으로 현저한 염증세포 침윤을 동반 한 피부 조직의 비후가 관찰되는 것으로 알려져 있으나 [6], 본 실험에서는 염증세포의 침윤은 비교적 약하게 일어난 반 면, 현저한 상피층(epidermis)의 비후로 인한 피부 두께의 증 가가 관찰되었다. 한편, $\mathrm{C} 57 \mathrm{~B} / \mathrm{L}$ 마우스는 외부의 화학물질에 의한 아토피 완화의 유도가 잘 알려져 있으며 [10], 본 실험의 결과에서도 피부상피 두께가 대조구에 비교하여 7.8 배 증가하 는 것으로 나타났다(Fig. 1). 한편 마우스의 등 부위에 일차적 인 감작화로 접촉성 피부염이 유발되지만(data not shown), 재감작에 의하여 보다 확실한 차이를 얻을 수 있었다. 재감작 은 귀 부위를 선택하였으며 이 경우에는 비교적 약한 농도의 $0.2 \% \mathrm{DNFB}$ 로 재감작시켰고, 재감작 후, 격일로 2주간 $\mathrm{CVL}$ 또는 산쑥과 자소옆 처리의 CVL 추출물을 처리하였다. 그 결 과, 아주 흥미롭게도 DNFB 처리에 의해 상피, 진피 및 피부 전체 두께가 현저하게 감소하였다(data not shown). 특히 상 피의 두께는 여러 가지 진피 내부의 면역세포가 표피로 이동 하여 이들 표피의 두께의 비후정도가 상이하게 되므로 이의 두께 정도를 비교하였다. Fig. 1에서 보는 바와 같이 접촉성 피부염 유발군보다 1 차 왕겨초액 처리군에서는 약 $20 \%$ 의 수 준으로 급격하게 감소하였다. 왕겨초액은 그 특유의 이취가 특이하므로 이를 제거하고자 스크리닝을 수행하여 산쑥과 자 소옆을 첨가한 왕겨초액의 항알러지 활성도 동시에 확인하여 보았다. 그 결과, 산쑥은 효과가 없었으나 자소옆은 활성도 있으며(대조군의 약 $18 \%$ 수준), 자소옆의 첨가로 인한 masking 효과는 이들을 이용한 향장소재 개발시 매우 유용한 자료 로 사용될 수 있다고 판단된다.

Fig. 1의 결과를 바탕으로 피부상피를 직접 조직염색학적인 소견을 살펴 본 바, Fig. 2에서 보는 바와 같이 접촉성 피부염 유발군에서는 상피조직의 비후정도가 현저히 발달되어 있었 으나 CVL 등 몇 가지 샘플 처리로 인하여 이의 비후정도가 상당 수준 감소함을 알 수 있었다(약 18-31\%). 이 표본에서 직접 eosinophil의 수적 감소 여부를 살펴 본 결과도 표피의 비후정도가 감소하는 것과 상당히 유사함을 알 수 있었다 (data not shown).

이상의 결과로서 본 왕겨초액의 증류액 CVL 및 산쑥이나 자소옆 처리액은 $\mathrm{DNFB}$ 처리에 의한 마우스에서의 접촉성 피 


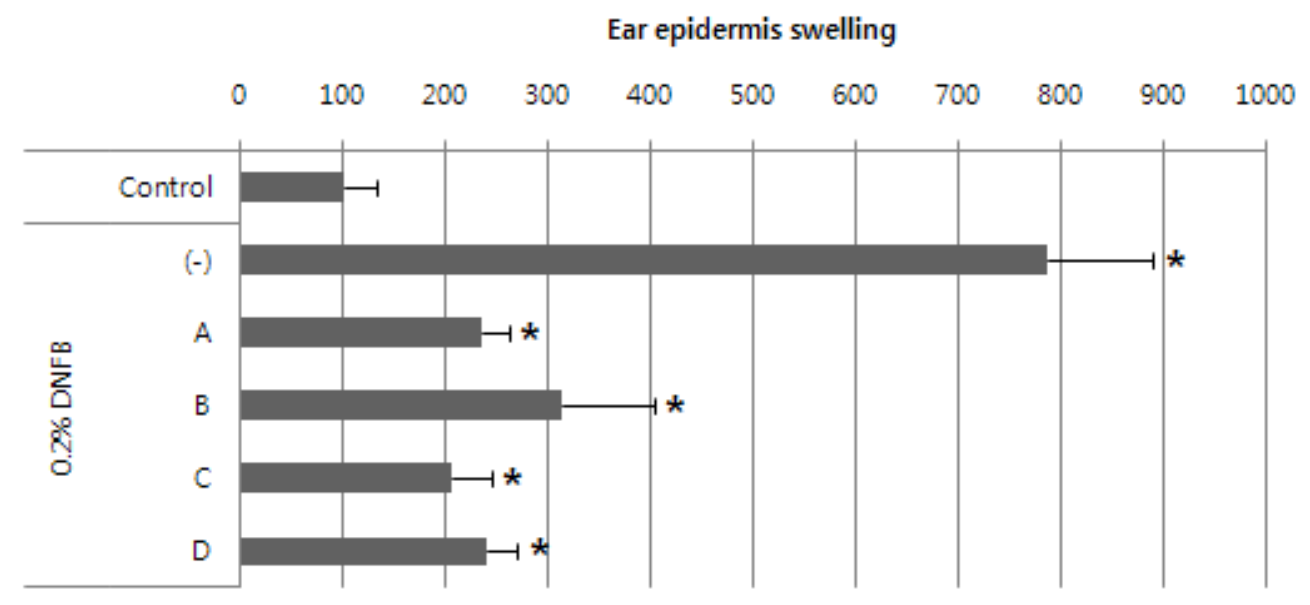

Fig. 1. Amelioration of the ear epidermis swelling by chaff vinegar liquor in a DNFB-induced allergic mouse model. DNFB (100 $\mathrm{ul}$ of $0.5 \% \mathrm{DNCB} /$ dorsal area) was spread on the back of each mouse per day for 3 days in order to induce allergic sensitization. Resensitization was carried out to induce allergic responses with DNFB (100 ul of $0.2 \%$ ), and treated to mice with (A-D) or without (NT, and -) chaff vinegar liquor on every 2 days for 2 weeks. NT, not treated; -, 0.2\% DNFB alone; A, 1st purified chaff vinegar liquor; B, 1st purified chaff vinegar liquor supplemented with of Artemisia montana Pampan; C, 1st purified chaff vinegar liquor supplemented with of Perilla frutescens var. acuta; D, 2nd purified chaff vinegar liquor. Data denote the mean \pm SD. ${ }^{*}, p<0.05$ compared with $0.2 \%$ DNFB alone.

\section{$\operatorname{DNFB}(0.2 \%)$}

NT

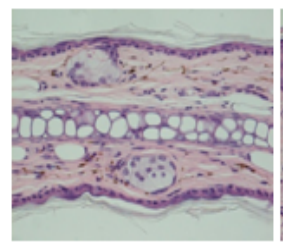

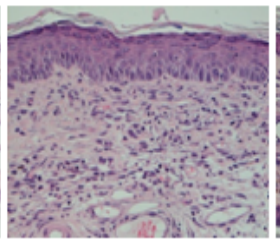

A

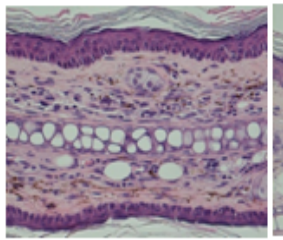

B

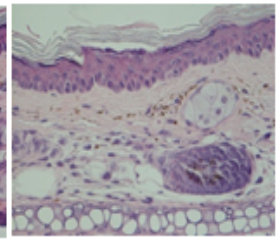

C

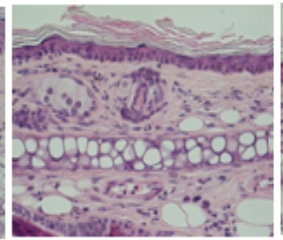

D

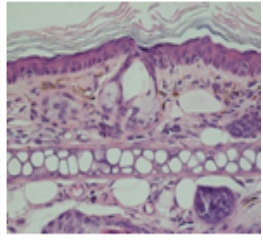

Fig. 2. Histochemical analysis of skin epidermis by chaff vinegar liquor treatment. DNFB (100 ul of $0.5 \%$ DNCB/dorsal area) was treated as shown in Fig. 1. H\&E staining was carried out as shown in Materials and method section. NT, not treated; -, $0.2 \%$ DNFB alone; A, 1st purified chaff vinegar liquor; B, 1st purified chaff vinegar liquor supplemented with of Artemisia montana Pampan; C, 1st purified chaff vinegar liquor supplemented with of Perilla frutescens var. acuta; D, 2nd purified chaff vinegar liquor. Data was represented with a classical observation of the three samples.

부염 반응을 효과적으로 완화시켜 주는 효과를 확인할 수 있 었다. 향후 접촉성 피부염에 관련된 cytokine (IL-4, IL-13, IL-25 등)이나 CCL7 등 chemotactic factors의 발현여부와 matrix metalloproteinase (MMPs)-2, -3, -9의 발현에 대한 mRNA 수준에서의 양적변화에 대한 비교실험의 결과는 왕겨초액을 이용한 향장소재화에 도움이 되리라 판단된다.

\section{감사의 글}

본 연구는 지경부 지역산업 선도기술개발사업의 지원에 의 하여 수행되었기에 이에 감사드립니다. 본 연구에 여러 가지 자료의 분석을 지원하여 준 허진철박사와 왕겨초액의 시료를
제공하여 준 대원GSI(주)에 감사드립니다.

\section{References}

1. Bergstresser, P. R. 1989. Sensitization and elicitation of inflammation in contact dermatitis. Immunol. Ser. 46, 219-245.

2. Falkeholm, L., C. A. Grant, A. Magnusson, and E. Moller. 2001. Xylene-free method for histological preparation: a multicentre evaluation. Lab Invest. 81, 1213-1221.

3. Gantner, F., H. Tenor, V. Gekeler, C. Schudt, A. Wendel, and A. Hatzelmann. 1997. Phosphodiesterase profiles of highly purified human peripheral blood leukocyte populations from normal and atopic individuals: a comparative 
study. J. Allergy Clin. Immunol. 100, 527-535.

4. Heo, J. C., J. R. Rho, T. H. Kim, S. Y. Kim, and S. H. Lee. 2008. An aqueous extract of green tea Camellia sinensis increases expression of Th1 cell-specific anti-asthmatic markers. Int. J. Mol. Med. 22, 763-768.

5. Hwang, Y. K., J. S. Chun, P. D. Yoo, J. Y. Ma, B. H. Hyun, S. U. Kim, K. T. Chang, and S. H. Lee. 2004. Occlusal reduction of unilateral molars influences change of stress-related hormones in rats. Scand. J. Lab. Animal Sci. 31, 73-77.

6. Jörundsson, E., C. M. Press, M. Ulvund, and T. Landsverk. 1999. Prominence of gammadelta $\mathrm{T}$ cells in the elicitation phase of dinitrochlorobenzene-induced contact hypersensitivity in lambs. Vet. Pathol. 36, 42-50.

7. Kimber, I., J. S. Pichowski, C. J. Betts, M. Cumberbatch, D. A. Basketter, and R. J. Dearman. 2001. Alternative approaches to the identification and characterization of chemical allergens. Toxicol. In Vitro 15, 307-312.

8. Meng, F., Y. Wei, and X. Yang. 2005. Iron content and bio- availability in rice. J. Trace Elem. Med. Biol. 18, 333-338.

9. Miller, J. S. and L. B. Schwartz. 1989. Human mast cell proteases and mast cell heterogeneity. Curr. Opin. Immunol. 1, 637-642.

10. Morioka, Y., K. Yamasaki, D. Leung, and R. L. Gallo. 2008. Cathelicidin antimicrobial peptides inhibit hyaluronan-induced cytokine release and modulate chronic allergic dermatitis. J. Immunol. 181, 3915-3922.

11. Pokharel, Y. R., S. C. Lim, S. C. Kim, T. H. Heo, H. K. Choi, and K. W. Kang. 2008. Sopungyangjae-tang inhibits development of dermatitis in Nc/Nga mice. Evid Based Complement Alternat Med. 5, 173-180.

12. Seo, Y. K., I. K. Lee, and S. H. Kim. 2009. Chaff-vinegar liquor exhibiting anti-allergic activities and compositions thereof. Korea Patent 10-0931529.

13. Wuthrich, B. 1989. Epidemiology of the allergic diseases: are they really on the increase? Int. Arch. Allergy Appl. Immunol. 90, 3-10.

\section{초록 : 왕겨초액의 추출물에 의한 아토피 완화 효과 비교}

이 상 한*

(경북대학교 식품생물산업연구소 및 식품공학과)

왕겨를 증류하여 생성된 왕겨초 증류액을 이용하여 접촉성 피부염에 어떤 영향이 있는지를 검토하였다. 왕겨 초 증류액 $(2 \%)$ 에 자소옆을 첨가한 샘플은 dinitrochlorobenzene에 의해 유발된 접촉성 피부염 질환 동물모델에서 피부상피조직의 비후정도를 약 $20 \%$ 정도의 수준으로 완화시키며, 이는 면역조직화학적인 방법으로 확인하였다. 이 결과로, 왕겨초 증류액은 아토피 완화 효과를 가지므로 이들의 적합한 조건을 확립한다면 향장소재 또는 이의 조성물로 유용하게 이용될 수 있다고 판단된다. 